УДК 004.05

[0000-0003-2007-9943] I. В. Миронець, к.т.н., доцент,

e-mail: irenmir30@gmail.com

Б. О. Луценко, магістрант

e-mail: bogdan.lutsenko11081997@gmail.com

Черкаський державний технологічний університет

б-р. Шевченка, 460, м. Черкаси, 18006, Україна

\title{
ФУНКЦІОНАЛЬНІ МОЖЛИВОСТІ ТА ОПТИМІЗАЦІЯ РОБОТИ АВТОМАТИЗОВАНОЇ СИСТЕМИ УПРАВЛІННЯ ТАТУ-ОБЛАДНАННЯМ
}

Проведена робота знайшла своє застосування в розвитку автоматизованих систем управління тату-обладнанням. Розширення культури татуювання в багатьох краӥнах світу стало поштовхом для розвитку технологій у цій галузі. Почали з'являтися нові концепції та їх реалізації, а існуючі - розширювали свої функціональні характеристики і можливості. Дослідження функціональних можливостей існуючих концепцій використання автоматизованих систем управління тату-обладнанням показало, щуо вони не є практичними у використанні та мають необтрунтовано високу иіну. Тому метою дослідження стало реалізувати найбільш ефективний функиіонал та дизайн шляхом проведення удосконалень існуючої системи управління татуобладнанням. Було проведено опитування серед майстрів, під час якого проводилися заміри часу роботи оптимізованої системи та їі аналогів, доступних широкому колу майстрів на ринку. Отримані результати повністю обтрунтували актуальність проведеного дослідження.

Ключові слова: автоматизовані системи управління, функиіональні можливості, мобільний додаток, оптимізація, тату-обладнання.

Вступ. Татуювання - це перманентний малюнок, створений на тілі шляхом впровадження під шкіру спеціалізованого пігменту за допомогою голок різних розмірів і заточки.

Спочатку татуювання наносили людям, які належали до різних культур протягом століть, проте лише сьогодні технологія і безпека цієї процедури досягли дійсно вражаючого рівня [1]. На це вплинуло багато факторів, одним із яких $\epsilon$ розвиток культури татуювання в багатьох країнах, а разом 3 нею - татуобладнання.

Технології розвиваються безперервно i динамічно. 3'являються нові концепції та їх реалізації, а існуючі - розширюють свої функціональні характеристики і можливості [2].

Однією 3 найбільш поширених концепцій, яка була впроваджена в розвиток татуобладнання, $\epsilon$ розробка мобільних додатків. Все це тому, що мобільні телефони (смартфони) стали невід'ємною частиною людського життя [3].

Завдяки широким функціональним можливостям цей гаджет вже давно витіснив стаціонарні телефони. Популярність смартфонів обумовлена наявністю великої кількості переваг над стаціонарними персональними комп'ютерами. Вони дають можливість виконувати

(C) I. В. Миронець, Б. О. Луценко, 2020 DOI: $10.24025 / 2306-4412.2 .2020 .196689$ значну частину задач користувача, таких як функції календаря, калькулятора, годинника, будильника та мультимедійного пристрою, при цьому залишаючись портативними.

На сьогоднішній день існує велика проблема з вибором тату-обладнання. Хоча ринок стрімко розвивається i 3 кожним днем 3'являється все більше і більше нових пристроїв, проте більшість із них зазвичай - це просто модифікація старих версій. Вони незручні у користуванні, тому що їх функціонал є замалим, а їхня ціна - невиправдано високою.

Провівши огляд і аналіз праць [2, 3, 4], було зроблено висновок, що дослідження функціональних можливостей та оптимізація автоматизованих систем управління татуобладнанням на основі існуючих концепцій $\epsilon$ актуальною науковою проблемою в цій галузі. Однією 3 найважливіших складових вирішення поставленої проблеми є статистичний аналіз даних усіх концепцій та визначення недоліків системи [5], необхідність розробки та покращення функціональних можливостей шляхом аналізу потреб користувачів.

Метою дослідження було реалізувати найбільш ефективний функціонал та дизайн мобільного додатка на основі проведення дослідження й удосконалення існуючої автома- 
тизованої системи управління татуобладнанням за рахунок зменшення робочого часу майстра, залишаючи незмінною продуктивність праці.

Для досягнення поставленої мети було сформульовано і вирішено такі завдання:

- на основі досліджень функціональних можливостей існуючих аналогів обгрунтувати актуальність оптимізації роботи автоматизованої системи управління татуобладнанням;

- розглянути загальні методики та методи проведення досліджень;

- реалізувати найбільш ефективний функціонал і дизайн мобільного додатка та провести аналіз отриманих результатів роботи.

Опис об'єкта та методу досліджень. Об'єктом дослідження є процес роботи автоматизованої системи для управління роботою тату-обладнання у вигляді мобільного додатка для операційної системи Android.

Базовий функціонал портативних пристроїв можна суттєво розширити за допомогою додатків. Вони відкривають нові канали зв'язку і можливості для ведення бізнесу, потенційно пропонуючи більш широкий доступ до інформаційних баз даних і основних послуг, удосконалюють інформаційні потоки підприємства, втримують прямий контакт із клієнтом, відстежують його поведінку і вподобання для досягнення маркетингових цілей.

Мобільні додатки мають велику кількість переваг для підприємців порівняно 3 веб-сайтами та програмним забезпеченням для персональних комп'ютерів. Успішний досвід таких українських компаній, як Нова Пошта, Rozetka та Prom.ua свідчить, що мобільні додатки здатні значно збільшити обсяг продажів. Відповідно до даних статистичного бюро Criteo $27 \%$ від усіх платежів у сфері електронної комерції за 2018 р. було проведено за допомогою мобільних додатків.

За результатами досліджень аналітичного агентства eMarketer, протягом останніх п'яти років спостерігається тенденція до збільшення обсягу часу, проведеного протягом дня в додатках, причому обсяг витраченого часу на перегляд мобільних веб-сторінок через браузер практично не змінився [6].

Робота тату-майстра полягає не лише у створенні певного зображення на тілі людини за допомогою спеціальних засобів, але й у вмінні контактувати з людьми, правильно кон-

(C) I. В. Миронець, Б. О. Луценко, 2020 DOI: $10.24025 / 2306-4412.2 .2020 .196689$ тролювати свій графік, вміти керувати своїм часом роботи та вести власну бухгалтерію.

Мобільний додаток для управління блоком живлення на відстані - це досить сучасний та інтуїтивно зрозумілий підхід до роботи. Його ціна разом з блоком живлення є достатньо малою, та все ж існує безліч можливостей для його удосконалення та оптимізації.

За допомогою огляду існуючих концепцій і після проведення спостережень за роботою майстрів, а також спеціального анкетування було визначено ряд нових функцій, яких не вистачало користувачам для повноцінної роботи.

Створення додаткових вікон у вигляді календаря, де можна буде робити помітки, яка робота буде проведена в точно визначену дату, день та що потрібно для реалізації цієї роботи, а найголовніше - скільки ця робота принесе прибутку, значно полегшить роботу майстра. В одному додатку можна легко помістити всі необхідні для користувача функції, аналогів яких не існує.

На основі дослідження функціональних можливостей існуючих концепцій було проведено оптимізацію автоматизованих систем управління тату-обладнанням.

Спочатку було проведено огляд і аналіз недоліків та переваг тих систем, які доступні нині на ринку. Було обрано напрям дослідження та проведено ознайомлення $з$ загальними методиками та методами проведення досліджень.

Особливості розглянутих рівнів наукового знання найбільш наочно виявляються при їх порівнянні та виявленні відмінностей між ними.

При порівнянні емпіричного і теоретичного рівнів пізнання було виявлено, що вони нерозривно пов'язані між собою і взаємодоповнюють один одного.

Так, емпіричне дослідження, виявляючи нові факти, нові дані спостереження та експерименту, стимулює розвиток теоретичного рівня, ставить перед ним нові проблеми та завдання. В свою чергу, теоретичне дослідження, розглядаючи та конкретизуючи теоретичний зміст науки, відкриває нові перспективи пояснення та передбачення фактів, і цим орієнтує та спрямовує емпіричне знання.

Для дослідження функціональних можливостей та оптимізації автоматизованих систем управління тату-обладнанням на основі існуючих концепцій більшу увагу було приді- 
лено саме емпіричному рівню. Це обумовлено специфікою застосовуваних методів та безпосередньою взаємодією дослідника 3 досліджуваним об'єктом. Оскільки в цьому дослідженні більшу увагу приділено експерименту та його результатам, тому після розгляду та вибору основної методики та методів досліджень було сформовано чіткий план дій [7].

Наукове знання і процес його здобуття характеризуються системністю і структурованістю. У структурі наукового знання виділяють емпіричний (дослідний) і теоретичний рівні. Сукупність дослідних заходів і методів забезпечує емпіричний і теоретичний етапи наукового дослідження [8].

На емпіричному рівні в цьому дослідженні було проведено збір фактів, первинне узагальнення, опис дослідних даних, систематизацію i класифікацію. Емпіричне дослідження спрямоване безпосередньо на об'єкт дослідження, відбувається на основі методів порівняння, виміру, спостерігання, експерименту, аналізу та ін. [9].

Емпіричні методи дослідження є визначальними в навчально-дослідній справі, що пов'язана 3 практикою, і забезпечують накопичення, фіксацію та узагальнення вихідного дослідного матеріалу. Отримані за допомогою цих методів дані $є$ основою для подальшого теоретичного осмислення пізнавальних процесів та створюють цілісну єдність наукового пізнання.

Спостереження - це систематичне, цілеспрямоване, спеціально організоване сприймання предметів і явищ об'єктивної дійсності, які виступають об'єктами дослідження. Як метод наукового пізнання спостереження дає можливість одержувати первинну інформацію у вигляді сукупності емпіричних тверджень [10].

Емпірична сукупність стає основою попередньої систематизації об'єктів реальності, роблячи їх вихідними об'єктами наукового дослідження.

У цьому дослідженні спостереження було проведено планомірно та стало одним із етапів, який допоміг інтуїтивно зрозуміти, як потрібно провести оптимізацію системи. За рахунок спостереження доповнився список функцій, яких не вистачало користувачеві. Це стало можливим після спостереження за роботою декількох майстрів 3 існуючими системами. В ході спостереження було сформовано логічні припущення.
Опитування дало більшу змогу отримати як фактичну інформацію, так і дані, за якими стало можливим провести оцінювання отриманих результатів.

Опитування було проведено в письмовій формі. Запитання були сформовані таким чином, що вони відповідали поставленій меті. Анкета складалася 3 декількох блоків запитань, пов'язаних не лише за рівнем періодичності використання певного функціоналу, а й за оцінкою об'єкта дослідження.

Головною метою анкетування було визначити, чи всі додаткові функції, які були сформовані в ході дослідження інших готових концепцій та на основі спостереження за майстрами, $\epsilon$ необхідними і подобаються майбутнім користувачам.

Опитування було проведено двічі - на початковому етапі дослідження, щоб зібрати всю необхідну інформацію для оптимізації, та на останніх етапах дослідження, щоб отримати результати роботи. Перше опитування відбувалося серед п'ятнадцяти майстрів, а друге - серед п'яти. Останні вже мали змогу користуватися продуктом протягом одного робочого дня, а потім пройти анкетування.

При порівнянні результатів опитування було виявлено, що більшій кількості користувачів оптимізація сподобалась, і вони готові 3 легкістю на неї перейти. Також явною перевагою став той факт, що частина майстрів ніколи раніше не працювала 3 подібним обладнанням.

Порівняння - це процес зіставлення 3 метою визначення схожості чи відмінності, а також знаходження загального, притаманного. Цей процес використовувався протягом усього дослідження на різних етапах для чіткого розуміння результату.

Для реалізації мобільного додатка було обрано середовище розробки Android Studio. Воно має багато переваг, притому мобільний додаток було розроблено для мобільної платформи Android.

Android Studio - безкоштовне середовище розробки на основі IntelliJ IDEA, надає інтегровані інструменти для розробки й налагодження додатків для платформи Android.

Процес розробки в середовищі Android Studio є дуже гнучким. Це досягається за рахунок відображення всіх робочих файлів у структурі проекту [11].

Вкрай корисною $є$ також можливість бачити всі візуальні зміни проекту в режимі реального часу. Причому SDK дає можливість 
протестувати майбутню роботу створеного продукту на різних пристроях.

У вбудованому емуляторі Android девайсів можна встановити різноманітні технічні конфігурації і дозволи екрану для тестування. Крім того, при використанні емуляції $\epsilon$ можливість отримати інформацію про наближений рівень продуктивності для того чи іншого пристрою.

Перш за все, потрібно було створити архітектуру майбутнього програмного продукту - ми створили пакети, кожен із яких відповідає за певний функціонал. В пакетах були створені класи, кожен із яких мав вузький обов'язок у програмі, а також прописали відносини між об'єктами.

Після того як написаний весь програмний код, необхідно створити apk-файл, встановити його на телефон та розпочати тестування.

Тестування додатка - це його перевірка різними методами і способами на працездатність. Тестування необхідно як новому, так i вже працюючому додатку для отримання гарантії його працездатності. Це дуже важливий етап розробки мобільних додатків. Вартість помилки в релізі $\epsilon$ дуже високою.

Мобільне тестування - складний процес: десятки різних роздільностей екрану, апаратні відмінності, кілька версій операційних систем, різні типи підключення до Інтернету, раптові обриви зв'язку тощо [12].

Після тестування додатки потрапляють в Google Play. Якщо опубліковані додатки мають якісь помилки, вони викликають бурхливу негативну реакцію. Користувачі залишають низькі оцінки й істеричні відгуки.

Після розробки було проведено поетапне тестування, яке зафіксувало всі помилки для обов'язкового виправлення. Після тестування цього програмного продукту було встановлено, що він не має критичних або ж блокуючих помилок.

При наявності готового мобільного додатка було проведено низку експериментів.

Вимірювання - це процедура визначення числового значення певної величини за допомогою одиниці виміру. Воно допоможе точно визначити всі поставлені цілі та занести їх у таблицю. Цінність цієї процедури полягає в тому, що вона дає точні, кількісно визначені відомості.

Вимірювання було спрямовано на швидкість роботи в цілому та на окремі процеси. Щоб експеримент пройшов вдало, в ньому брало участь п'ять майстрів. Спочатку вимірювання проводилося на обладнанні, 3 яким майстри працювали до експерименту, а потім вже на оптимізованих автоматизованих системах управління (таблиця 1).

Основним критерієм стосовно оптимізації системи був час, а саме - зменшити робочий час і залишити продуктивність на такому ж рівні або навіть збільшити іiі. Майстри виконували роботу, яка займала приблизно однакову кількість часу. Для підрахунку брався середній час усіх майстрів.

\section{Таблиця 1 - Результати вимірювань до та після оптимізації системи}

\begin{tabular}{|l|c|c|}
\hline \multicolumn{1}{|c|}{ Операції } & \multicolumn{1}{|c|}{$\begin{array}{c}\text { Час вимірювання } \\
\text { до оптимізації }\end{array}$} & $\begin{array}{c}\text { Час вимірювання } \\
\text { після оптимізації }\end{array}$ \\
\hline Підключення обладнання & 20 хв. & 10 хв. \\
\hline Налаштування обладнання & 15 хв. & 5 хв. \\
\hline Кількість часу на створення роботи & 3 год. & 2 год. 55 хв. \\
\hline Прибирання робочого місця & 10 хв. \\
\hline Консультація з новим клієнтом & 30 хв. & 20 хв. \\
\hline $\begin{array}{l}\text { Підготовка до наступного робочого } \\
\text { дня }\end{array}$ & 30 хв. & 20 хв. \\
\hline Разом: & 4 год. 35 хв. & 3 год. 55 хв. \\
\hline
\end{tabular}

Підключення тату-обладнання - це процес, коли майстер готує своє робоче місце перед тим, як розпочати роботу. Потрібно про(C) I. В. Миронець, Б. О. Луценко, 2020 DOI: $10.24025 / 2306-4412.2 .2020 .196689$ дезінфікувати всі робочі поверхні, а найголовніше - підготувати своє обладнання до роботи. Зазвичай використовують дві робочі поверхні: 
перша - де виконують саме татуювання і друга - для розміщення обладнання й одноразових матеріалів, таких як фарби, салфетки тощо. Ці поверхні повністю стерилізуються, оскільки простої стерилізації недостатньо, також використовуються одноразові елементи для підтримки цієї стерильності (бар'єрний захист для проводів і машинки, для проводів він виглядає як спеціальний рукав $з$ поліетилену, а для машинки - як поліетиленовий бокс).

Такий елемент, як блок живлення також потребує стерильності, але не існує засобів для його стерилізації, а спеціальні поліетиленові бокси для нього не передбачені, тому він огортається харчовою плівкою, щоб завжди залишатися чистим і щоб на ньому не залишалися сліди фарби та крові, адже під час роботи майстер завжди контактує 3 ним. Однак харчова плівка має великий недолік - блок живлення, перебуваючи в ній, повністю втрачає можливість тепловіддачі, а це призводить до перегрівання та пошкодження.

Ідея модернізації блока живлення, насправді, дуже проста, проте вона кардинально спрощує роботу тату-майстра, починаючи від зручності користування і закінчуючи стерильністю, а стерильність, в свою чергу, зводить до мінімуму шанс занести інфекцію.

Мобільний додаток дає можливість легко керувати блоком живлення, який може бути розташованим подалі від робочого місця $\mathrm{i}$ не займати робочий простір. Також це буде доречно для зберігання стерильності робочого місця, що так необхідно в цій сфері роботи, адже від цього залежить якість виконаної роботи та гарантія безпеки здоров'я клієнта - не потрібно буде постійно торкатися сторонніх предметів.

Не менш важливим фактором $є$ те, що майстер не витрачає зайвий час на бар'єрний захист, а також те, що сам блок живлення досить малий i має магнітне кріплення. Його можна закріпити де завгодно, і він не буде займати багато місця. Цей фактор дав змогу скоротити час підготовки в два рази. За допомогою вимірювання було визначено, що середній час на підготовку цього етапу займав 20 хв., а після оптимізації - 10 хв.

Налаштування тату-обладнання - це процес, коли майстер все зібрав, проте йому потрібно зробити додаткові специфічні налаштування під конкретну роботу. Це може бути швидкість, 3 якою рухається голка в татумашинці. Вона регулюється за допомогою вольтажу на блоці живлення. Майстер використовує в середньому від двох до п’яти конфігурацій голок під час роботи, тому йому потрібно налаштуватися на кожну з них перед роботою.

Інтерфейс у мобільного додатка є оптимально простим та зручним у користуванні. Він максимально наповнений усією необхідною інформацією. В ньому розташовано кілька вікон з вибором функцій, які потрібні та не будуть відволікати.

Робота такого пристрою дуже проста i не вимагає налаштування апаратної конфігурації. За допомого додатка можна не тільки регулювати вольтаж, як це робиться в аналогах, а й мати власну базу даних. Це допомогло скоротити час в три рази - від 15 хв. у середньому перед оптимізацією до 5 хв. після їі впровадження.

Час, який майстер витрачає на створення зображення на тілі, хоча і входить до етапів, які вимірювалися, проте фактично залежить від здібностей і швидкості роботи самого майстра. Для точнішого проведення експерименту майстрів було заздалегідь попереджено, щоб вибрана ними робота не займала більше трьох годин для реалізації. Тому показники на цьому етапі відрізняються лише на п'ять хвилин.

Прибирання робочого місця - це процес, коли майстер після закінчення своєї роботи має розібрати своє тату-обладнання та продезінфікувати робочі поверхні. Цей етап дуже схожий на підключення, але проводиться у зворотному напрямку. Оскільки час при підключенні був меншим через спрощення системи, аналогічно - час прибирання робочого місця став удвічі швидшим - він зменшився від 10 хв. до 5 хв.

Консультація 3 новим клієнтом відбувається в кінці робочого дня. Зазвичай під час цього процесу майстер проводить бесіди 3 приводу розмірів, стилю, розміщення майбутнього татуювання. Також головною темою $\epsilon$ ціна та дата, коли буде проведена наступна зустріч для реалізації проекту.

За допомогою встановлених у додатку додаткових функцій у вигляді календаря цей процес пришвидшився, а найголовніше - став зручнішим. Інноваційним $є$ те, що функціональні можливості дають змогу використовувати додаток не лише під час підготовки та нанесення татуювання, а й у звичайній робочій атмосфері. 
Є можливість проглядати свій графік наперед, легко його коригувати, мати зворотний зв'язок із клієнтом. Це реалізовано за допомогою встановлення додаткового вікна в програмі, що містить календар, кожний день якого підсвічений. Зелений колір означає, що цей день вільний, червоний - що майстер має роботу. Якщо перейти до вибраного дня, там $\epsilon$ детальна інформація про те, яку саме роботу повинен виконати майстер, скільки він на цьому може заробити, а також які одноразові матеріали йому потрібні. Це пришвидшує й підготовку майстра до наступного робочого дня.

Останні два етапи можна об'єднати, адже функціональні можливості додатка для них були сформовані одночасно, і результат вимірювань показав, що ця оптимізація робочого процесу пришвидшила час роботи на 10 хв.

Раніше майстру потрібно було в середньому 30 хв. на консультацію та стільки ж часу на підготовку до наступного робочого дня. 3 використанням додатка цей час зменшився до 20 хв. на обох етапах.

Результати цього експерименту показали, що робота майстрів в цілому пришвидшилася на 40 хв. Зазвичай у середньому майстру потрібно було на реалізацію невеликого проекту та підготовку до наступного робочого дня разом 3 консультацією 4 год. 35 хв. Цей час вдалося зменшити до 3 год. 55 хв. Отже, мета зменшити робочий час, а продуктивність залишити на тому ж рівні була повністю досягнута. Експеримент можна вважати успішним.

Висновки. Нині технології розвиваються безперервно і динамічно, разом з ними йде й активна розробка i вдосконалення татуобладнання. Незважаючи на це, процеси стандартизації та глобалізації почалися порівняно недавно, тому існує не так багато готових рішень і вони дуже схожі за своєю реалізацією. Це обумовлено тим, що насправді серійних виробників тату-обладнання на ринку не так багато, проте завдяки великій зацікавленості людей у тату-мистецтві за останні кілька років відбувся неймовірний поштовх ринку в розвитку тату-обладнання, інтеграції в нього нових пристроїв і сервісів.

Висновки. Отже, керування блоком живлення за допомогою мобільного додатка надає користувачам такі переваги: підвищення комфорту в роботі, стерильність, яка, в свою чергу, зводить до мінімуму шанс занести інфекцію, та збереження специфічних на-

(C) I. В. Миронець, Б. О. Луценко, 2020 DOI: $10.24025 / 2306-4412.2 .2020 .196689$ лаштувань, які пришвидшують і спрощують роботу майстра.

Інноваційним $є$ те, що функціональні можливості дають змогу використовувати додаток не лише під час підготовки та нанесення татуювання, а й у звичайній робочій атмосфері. $€$ можливість проглядати свій графік наперед, легко його коригувати, мати зворотний зв'язок із клієнтом.

У процесі вирішення поставлених завдань у роботі одержано наступні результати:

- на основі досліджень функціональних можливостей існуючих аналогів автоматизованих систем управління татуобладнанням було зроблено обгрунтування актуальності оптимізації їх роботи;

- розглянуто загальні методики та методи досліджень;

- реалізовано найбільш ефективний функціонал і дизайн мобільного додатка, а також проведено аналіз та обгрунтування отриманих результатів дослідження.

\section{Список використаних джерел}

[1] Карл Циммар, Науковий пігмент: татуювання одержсимих наукою. Великобританія: Келмскотт-пресс, 2011.

[2] О. В. Андрощук, Ю. В. Кондратенко, О. В. Головченко, Т. О. Ворона, та М. В. Петрушен, "Інформаційні технології та їх вплив на розвиток суспільства", Збірник наукових пращь Центру воєнностратегічних досліджень Національного університету оборони України імені Івана Черняховського, № 1 (50), 2014.

[3] К. С. Амнелин, и О. Н. Граничин, Введение в разработку приложений для мобильных платформ. ВВМ, 2011.

[4] Т. М. Корпанюк, та Я. І. Мулик, "Застосування мобільних", Ефективна економі$\kappa a$ : електрон. фахове вид., № 1 (3), 2018.

[5] Е. В. Чекотовський, Статистичні мето$\partial u$ : навч. посіб. Київ, Україна: Знання, 2016.

[6] Global Commerce Review. [Online]. Available: https://bit.ly/2AkZ5Re

[7] Jaime Levy, UX strategy: how to device innovative digital products that people want. O'Reilly Media, 2015.

[8] В. I. Зацерковний, I. В. Тішаєв, та В. К. Демидов, Методологія наукових досліджень: навч. посіб. Ніжин, Україна, 2012. 
[9] О. О. Железняк, та I. В. Корнієнко, Наука та наукові дослідження: навч. посіб. Нiжин, Україна, 2007.

[10] О. В. Колєсніков, Основи наукових досліджень: навч. посіб., 2-ге вид., випр. та доп. Київ, Україна, 2011.

[11] А. Л. Голощапов, Google Android. Создание приложений для смартфонов и планшетных ПК. Санкт-Петербург, Россия, 2012.

[12] В. П. Котляров, Основи тестування програмного забезпечення. Біном, 2009.

\section{References}

[1] Carl Zimmar, Scientific pigment: tattoos of obsessed with science. UK: Kelmscott Press, 2011.

[2] O. V. Androschuk, Yu. V. Kondratenko, O. V. Golovchenko, T. O. Vorona, and M. V. Petrushen, "Information technologies and their influence on society development", Zbirnyk naukovykh prats Tsentru voiennostratehichnykh doslidzhen Natsionalnoho universytetu oborony Ukrainy imeni Ivana Cherniakhovskoho, no. 1 (50), 2014 [in Ukrainian].

[3] K. S. Amnelin, and O. N. Granichyn, Introduction to the development of applications for mobile platforms. VVM, 2011 [in Russian].
[4] T. M. Korpaniuk, and Ya. I. Mulik. "Mobile application", Efektyvna ekonomika: electronic professional ed., no. 1 (3), 2018 [in Ukrainian].

[5] E. V. Chekotovsky, Statistical methods: textbook. Kyiv, Ukraine: Znannya, 2016 [in Ukrainian].

[6] Global Commerce Review. [Online]. Available: https://bit.ly/2AkZ5Re

[7] Jaime Levy, UX strategy: how to device innovative digital products that people want. O'Reilly Media, 2015.

[8] V. I. Zatserkovny, I. V. Tishaev, and V. K. Demidov, Methodology of scientific research: textbook. Nizhyn, Ukraine, 2012 [in Ukrainian].

[9] O. O. Zheleznyak, and I. V. Kornienko, Science and scientific research: textbook. Nizhin, Ukraine, 2007 [in Ukrainian].

[10] O. V. Kolesnikov, Fundamentals of scientific research: textbook, the 2 nd ed., cor. and suppl., Kyiv, Ukraine, 2011 [in Ukrainian].

[11] A. L. Goloshchapov, Google Android. Creating applications for smartphones and tablets. St. Petersburg, Russia, 2012 [in Russian].

[12] V. P. Kotlyarov, The basics of testing software protection. Binom, 2009 [in Russian].

I. V. Myronets, $P$ h. D., associate professor, e-mail: irenmir30@gmail.com,

L. B. Lutsenko, master

e-mail: bogdan.lutsenko11081997@gmail.com

Cherkasy State Technological University,

Shevchenko blvd, 460, Cherkasy, 18006, Ukraine

\section{FUNCTIONAL POSSIBILITIES AND OPTIMIZATION OF WORK OF AUTOMATED TATTOO-EQUIPMENT CONTROL SYSTEM}

Tattoo culture is developing rapidly in the modern world, along with its tattoo equipment. The expansion of tattoo culture in many countries of the world has been an impetus for the development of technologies in this field. New concepts and their implementations beg in to emerge, and existing concepts expand their functionality and capabilities. The development of mobile phones is one of the most popular concepts that has been introduced in the development of tattoo equipment. This factor helps to integrate all workflows in a smartphone, which greatly improves the work. Since the indus- 
try is fairly new, there are many prototypes, but few solutions are available. A study of the functionality of existing concepts for the use of automated tattoo-equipment control systems has shown that they are not practical to use and have an unreasonably high price. Therefore, the purpose of the study is to realize the most effective functionality and design by carrying out improvements of the existing tattoo-equipment control systems, to reduce the master's time, but leave productivity at the same level or even raise it. A survey has been conducted among the masters, during which time measurements of the work of optimized system and its analogues available to a wide range of masters in the market have been carried out. Based on the review of analogues and peculiarities of work in the tattoo sphere, the relevance of the development is substantiated. The most effective functionality and design are implemented. The data above shows that the optimization of the application has increased the level of comfort in the workplace, implemented specific settings that accelerate and simplify the master's work.

Keywords: automated control systems, functionality, mobile application, optimization, tattooequipment.

Стаття надійшла 03.01.2020

Прийнято 04.02.2020 